\title{
Orbetello, a fortress on the water. A research for the valorization of the city and its bastioned front
}

\author{
Alessio Cartei ${ }^{a}$, Marco Giorgio Bevilacqua ${ }^{b}$, Caterina Calvanic, Roberto Pierini ${ }^{\text {, }}$, \\ Domenico Taddei ${ }^{\mathrm{e}}$
}

University of Pisa, Italy, ${ }^{a}$ alessio.cartei@ hotmail.it, ${ }^{\mathrm{b}}$ mg.bevilacqua@ing.unipi.it, ${ }^{\mathrm{c}}$ caterina.calvani@libero.it,

${ }^{\mathrm{d}}$ r.pierini@ing.unipi.it, ${ }^{\mathrm{e}}$ d.taddei@ing.unipi.it

\begin{abstract}
Orbetello is located in the Southern Tuscany, at the centre of a lagoon. Founded by the Etruscans, its strategic position it has been disputed for centuries by the major European powers until 1559 when it became the capital of the small Spanish State of Presidios. From that moment, the urban fortifications were continuously subjected to modifications and updates, until the final layout in the 17th century. The current state of general neglect and the recent urban expansion of the city have greatly compromised the integrity of these fortifications. This paper intends to report the results of a research that, starting from an in-deep historical analysis, aims to define some guidelines for the recovery of the city walls and their historical value in a wider project of urban regeneration.
\end{abstract}

Keywords: Orbetello, bastions, State of the Presidios, redevelopment.

\section{Introduction}

The ancient stronghold of Orbertello is located in the Southern Tuscany, in front of Mount Argentario, in the centre of a natural lagoon enclosed by two tombolos (fig. 1).

Founded by the Etruscans, Orbetello reached its greatest extension in the $17^{\text {th }}$ Century, when it became the capital of the small Spanish State of the Presidios. At that time, its fortifications were globally reconceived, with the creation of a new bastioned front 'alla moderna'.

The bastioned front has been preserved almost intact until the Fascist period, when the construction of a new seaplane base determined the partial demolition of the ditch and the outworks.

The current state of general neglect and the recent landward expansion of the city have greatly compromised the integrity of these fortifications.
This study aims to define a project for the recovery of Orbetello bastioned front and of its historical memory, in a wider context of urban redevelopment.

The study started from an in-depth historical analysis, which has permitted to reconstruct the evolution of the city and its defense system from the $16^{\text {th }}$ century to date; the results of the analysis constituted also a necessary basis for the subsequent investigations. We conducted then an urban analysis, which allowed to identify criticisms and values of the area and to define the main guidelines for action, as described below.

\section{Historical evolution of the fortifications}

Many archaeological finds have indisputably demonstrated that Orbetello was a fortified city since ancient times. Remains of the Etruscan 


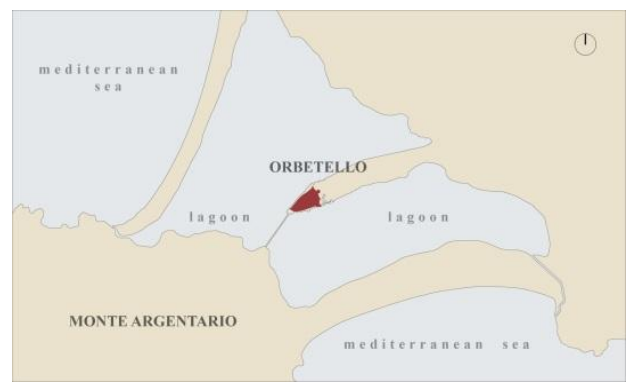

Fig. 1- Orbetello geographical location

polygonal walls, of the third type, dated to the second half of the 4th century BC (Carandini, 1985), still appear along the city sides overlooking the lagoon (fig. 2). There are no traces of the original system of gates, except for the south-eastern one, plausibly connected to infrastructures for lightweight shipping (Raveggi, 1939).

The few historical evidences from the Roman period indicate that, as early as the second half of the 3rd century BC, life in Orbetello slowly began to run out, on behalf of the thriving colony of Cosa. The period of decline lasted until 805, when Pope Leo III and Charlemagne brought the city back to the top with a donation of an extensive territory to the Abbey of 'Tre Fontane' (Bischi, 1994).

For its commercial strategic position, some of the most important feudal families in Tuscany Aldobrandeschi, Orvieto, and Orsini - contested Orbetello. For this reason, as early as the 12th Century, part of the ancient Etruscan walls was included in a new defensive system, with towers and fortified doors (Maioli Urbini, 1985). The lagoon, with its shallow water - and therefore not navigable by big warships - allowed the coastward side of the medieval walls to remain almost unchanged over time. The same cannot be said for the landward side, more vulnerable to the introduction of firearms from the 15th century onwards (fig. 3).

The landward part of the medieval fortifications was composed by the 'Torre Ghibellina', built between the end of the 13th century and beginning of the 14th century in defense of the ancient 'Porta a Terra' and then incorporated in the 'Rocca'; the 'Torre Senese' and the 'Porta del
Soccorso', provided with a drawbridge (Cardarelli, 1924 - 25).

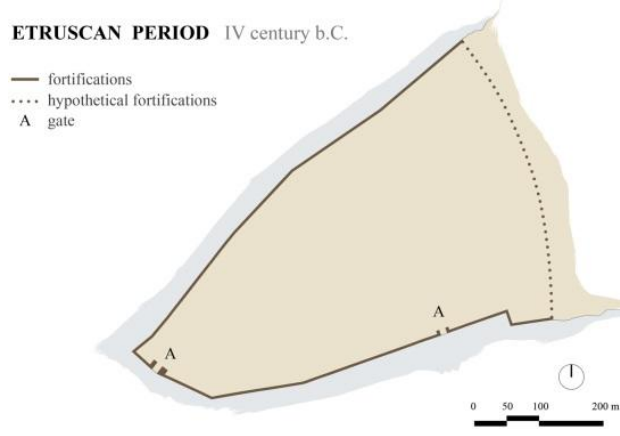

Fig. 2- Etruscan period, hypothetical reconstruction of the city walls

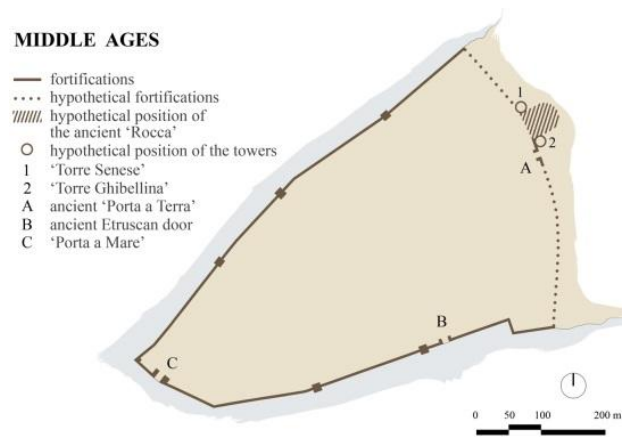

Fig. 3- City walls in the Middle Age, hypothetical reconstruction

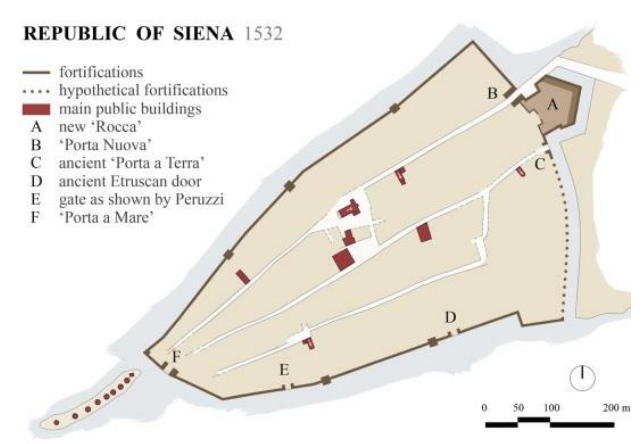

Fig. 4- City plan in the early 16 th century

In 1414, Orbetello was conquered by the Republic of Siena, which repeatedly intervened for the strengthening of the defense system. In 
1468, the work was entrusted to the architect Lorenzo di Pietro, known as 'il Vecchietta', who built the 'Porta a Mare' - also known as 'Porta Mulina' - reorganized the accesses of the landward side of the walls and probably restructured the 'Rocca' (Maioli Urbini, 1985; Raveggi, 1933).

The first representation of the defense system is in some sketches drawn by Baldassarre Peruzzi in 1532 (ASSi, Concistoro 2207; GFU, photos n. 170673 and 174371, from Addonisio, 2000, pp. 46-49). These sketches show that the western part of the walls had already the current trend and length, and that in the eastern part the ancient Etruscan door was still open. The 'Rocca', represented as it is today, played a central role in the landward defense of the city and of the main door (fig. 4).

A second phase of works started in 1543 by the architect Anton Maria Lari, who built a new tower towards Talamone, and the bastions 'Santa Maria' and 'Burgos' in fagots and earth. The ancient 'Porta Terra' was definitively walled up and the 'Porta Nuova' was renovated, as already suggested by Peruzzi (Addonisio, 2000). 'Cavalieri', casemates, counter-mines, embankments, embrasures, and any other works that the modernization required were built.

In 1546, Pietro Cataneo, who in Orbetello took some ideas for the development of his ideal city model (Milanesi, 1885, p.32), continued Anton Maria Lari's project.

Under the Spanish dominion, the bastioned front of Orbetello was continuously developed until the 17th-century final layout (figs. 5, 6).

The landward curtain walls were marked by four bastions, at a distance of about 100 meters from each other: 'Bastione Arcos', 'Bastione della Fortezza', 'Bastione Santa Maria' and 'Bastione Guzman'. These bastions, already initiated by the Republic of Siena, were bricked over and equipped with artillery and watchtowers in the second half of the 17th century (Maioli Urbini 1985). Restoration works started probably first on the 'Rocca' and on the 'Bastione Santa Maria'; then the 'Bastione Guzman', heavily damaged by the war, was rebuilt towards the end of the century. The 'Bastione Arcos' was the last to be completed, even in 1692.

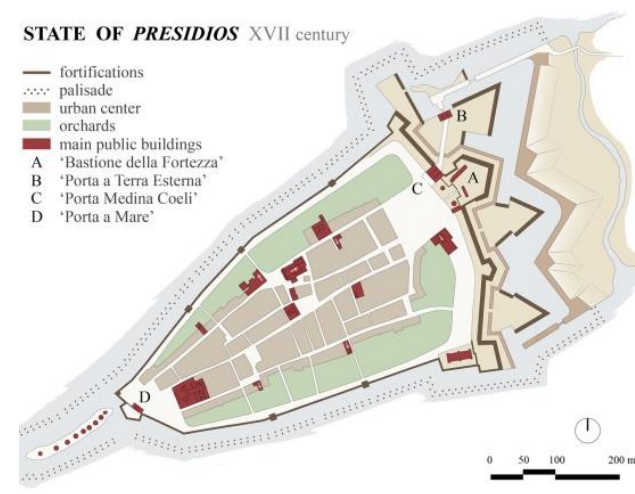

Fig. 5- Plan of the city, State of the Presidios, 17th century

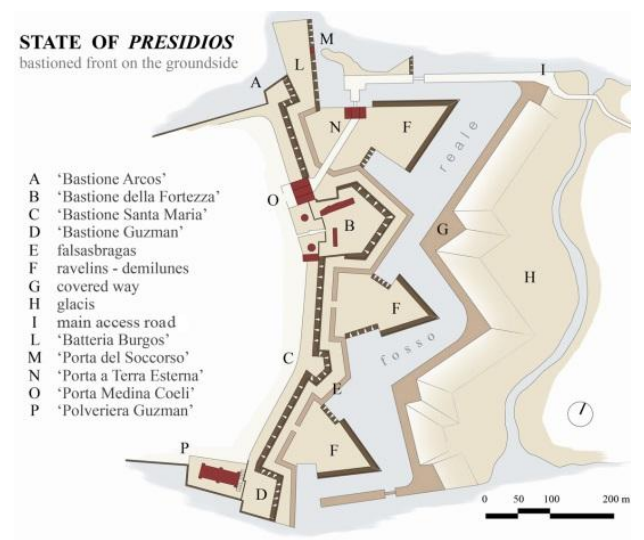

Fig. 6- Orbetello 17th-century landward bastioned front

The topography of Orbetello heavily conditioned the project of the bastions. The lack of space in fact imposed the construction of narrow gorges and short and straight flanks (Caciagli, 1992).

The bastioned front was completed by a falsasbragas and three ravelins-demilunes, dating before 1646. The 'Fosso Reale', with covered way, divided the fortifications from the mainland and extending across the width of the isthmus, transformed the city into a real island. The system was completed by a second ditch the 'Fosso degli Spalti' - dug at the foot of a glacis, shaped with steep slope. 


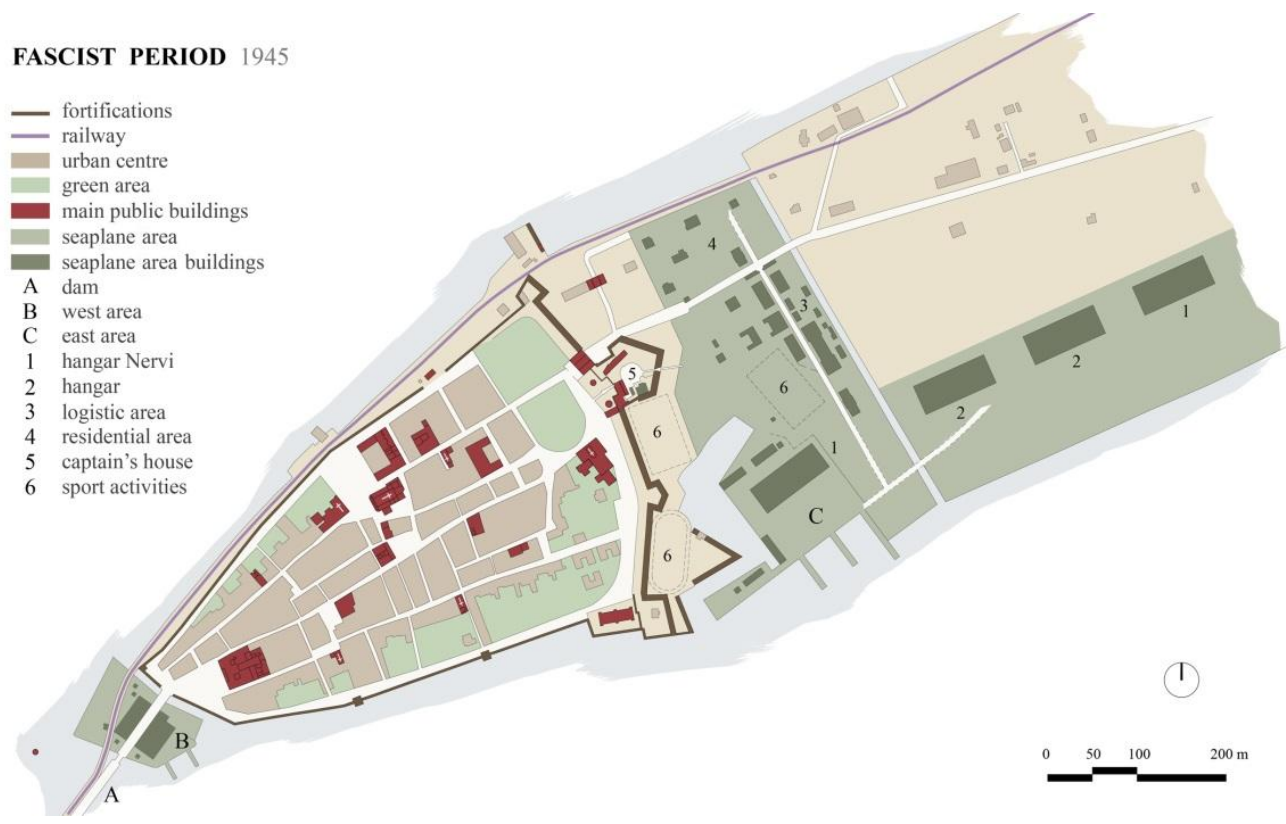

Fig. 7- Plan of the city during the Fascist period

Even the gates of the city were completely renovated. The 'Porta del Soccorso', built in 1620, was the first in chronological order; then, in 1692, the 'Porta a Terra Esterna' was completed by the architect Ferdinando De Grunembergh; in 1697, the 'Porta a Terra Senese' was reopened with the name of 'Porta Nuova' or 'Porta Medina Coeli'.

De Grunembergh coordinated much of the works of the last years of the 17th century. He worked also at the 'Bastione Arcos' and at the 'Polveriera Guzman', one of the most valuable works of the defensive system of Orbetello. The fortifications of the sides overlooking the lagoon were not subjected to great renovation: the Spanish architects just consolidated the original layout.

The urban structure was already well defined at the beginning of the 17th Century. Comparing the drawings by Peruzzi with the most detailed ones related to the siege in 1646 (Rombai et al., 1979, pp 210 - 228; Ademollo, 1883) you can notice that the roadway system is already set on three main longitudinal axes, connecting the stronghold ends. Inside the walls, the built-up area was surrounded by orchards; the pomerium completed the structure of the city.
After the Italian Unification, the defense system lost its importance and began its slow decay. Already in 1842, the construction of the dam between Orbetello and Monte Argentario produced the demolition of the 'Porta a Mare'. In 1911, the construction of a new railway line, along the west coast, led to the demolition of part of the 'Batteria Burgos' and the opening of some gaps in the ancient medieval walls.

With the construction of the seaplane base during the Fascist period, part of the 17thcentury fortifications has been irretrievably lost (fig. 7).

The construction of the seaplane base started in 1920 in the area of the glacis; therefore, up to 1945 , the base was subject to continuous expansion works that required the burial of most of the ditch, the demolition of two ravelins and of the covered way. The Commandant's building was finally placed on the 'Rocca'.

During the Second World War, the retreating Germans Army destroyed most of the main seaplane-base buildings, among which the well-known hangars designed by Pier Luigi Nervi. 
The landward urban expansion after the Second World War has also contributed to the final state of neglect in which these important examples of fortifications 'alla moderna' are today.

\section{Urban Analysis}

The urban analysis aimed at the definition of an in-depth knowledge of Orbetello's historical centre, the area of the former seaplane base and the most recent Neghelli quarter (fig. 8). The study started from the analysis of the road system, with the identification of the main arterial roads and of their traffic level. Then the study focused on the analysis of land uses, highlighting the public green areas, their level of use and the offered services. Finally, the urban tissue was analyzed, in order to identify the use of buildings, their typological characteristics, the construction period and the state of preservation. Among the architectural monuments, particular attention was paid to the remains of the 17 thcentury fortifications, which are in extremely precarious conditions: the walkway over the walls is used for not well-suited activities; the 'Rocca' is in a dreadful state and the historical buildings over time have become places of social degradation. As regards the coastward side of the fortifications, several gaps have been opened for connecting the historical centre with new parking area; the ancient medieval towers have been transformed in staircases.

The restoration of the 'Polveriera Guzman', converted today in an archaeological museum, represents the only example of correct management of the historical architectural heritage in Orbetello. The tourist interest that this intervention has moved is a clear sign of the attractive potentiality of the area.

However, the only conservative restoration of the fortifications is not sufficient for their valorization, if it does not refer to a wider regeneration program that must involve the city in its whole.

The 'Porta del Soccorso' and the 'Porta a Terra Esterna', even if recently restored, are clear examples of what we say: the 20th-century urban expansion has completely detached the doors from the rest of the fortifications, leaving them hidden in a built-up area without identity.

For these reasons, the recovery of the former airplane base area is surely of primary importance. This large green area, at the foot of the fortifications, does not perform the function of urban park; the sports activities that are in the area are misplaced too close to the walls, without an adequate respect zone. All these elements greatly contribute to the degradation of the city walls. The recovery of the area should not forget also the historical importance of the seaplane base, which gave prestige to this small city, thanks to Italo Balbo's transatlantic flights, commemorated today by a monument in the 'Parco delle Crociere'.

The urban analysis showed also that Orbetello's urban development has been influenced by the presence of the fortifications. The historic centre, closed within the fortifications, has limited traffic and is surrounded by a single ring road. Since the '1950s, the saturation of the centre has brought the urban expansion outside the walls, over the seaplane base, but without following a precise program: the Neghelli quarter, in fact, is fragmented and anonymous. These two distinct nuclei - the historical centre and the Neghelli quarter - are separated by the 'Fosso Glacis', which connects the western part of the lagoon with the eastern one. The road that runs through the tombolo and leads up to Monte Argentario is the only link between these two poles. This very busy artery, passing under the 'Porta Medina Coeli', represents therefore one of the main criticisms.

The restoration of the fortifications and the redevelopment of the former seaplane base should be designed in a perspective aimed at overcoming the break between the old town and the rest of the territory.

It is clear, therefore, that the site may represent a great resource for the city. This is what emerges also from the analysis of the existing urban regulations, even if their provisions are unfortunately generic and sometimes contradictory. The 'Piano Strutturale' takes into 


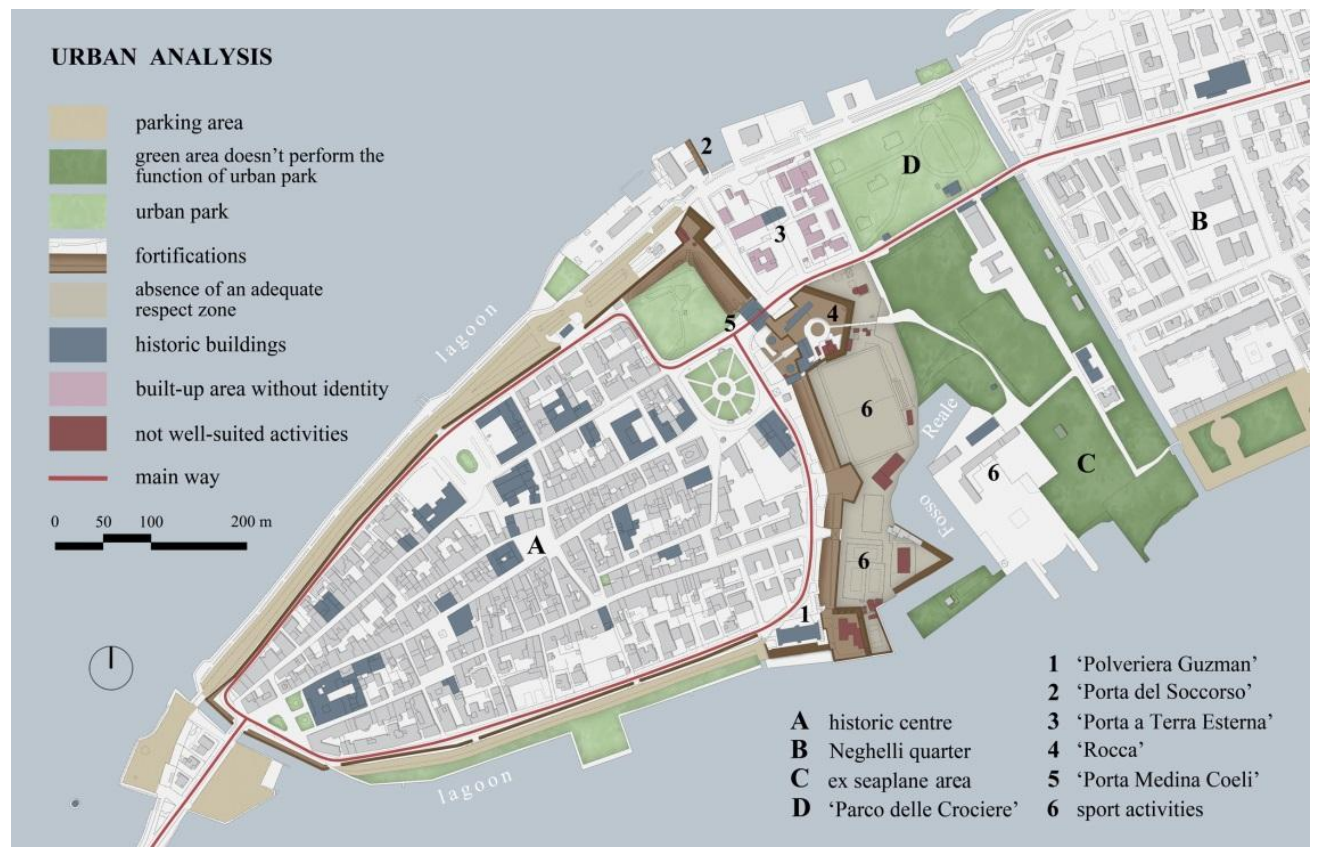

Fig. 8- Summery scheme of the urban analysis

account the risks identified by the 'Piano di Indirizzo Territoriale' related to a possible loss of the historical value of the walls, and for this reasons provides a strategy for the recovery of the aesthetic-perceptive values of the area. The 'Regolamento Urbanistico' does not yet correctly implement these predictions: its actions, in fact, are not very incisive and sufficient, because they lack in a general view.

This situation is aggravated by the absence of a 'Piano Attuativo'. The great economic investments that these interventions require are probably one of the causes that over time have hindered the redevelopment of the fortifications. Only recently, the new City Government has promoted a participatory process for the valorization of the former seaplane base area and of the city walls.

\section{Intervention guidelines}

The study allowed to define a strategy for the redevelopment of the historical heritage of Orbetello, which can be summarized in the following intervention guidelines (fig. 9).
1. The reorganization of the road network represents the first step. It aims to decrease the traffic on the main road and, therefore, to preserve the 'Porta Medina Coeli'. Traffic may be redirect along the western side of the lagoon, realizing a dual carriageway in the existing road. This would also allow a greater permeability between the 'Parco delle Crociere' and the former seaplane base area. The traffic block of the road near the walls would further maximize the usability of the park.

2. With regard to the restoration and the valorization of the fortifications, bastions and curtain walls should not be seen as mere monuments but as spaces for compatible activities. To this end, the realization of a panoramic walkway above the walls, through the 'Rocca' and the 'Porta Medina Coeli', could give back a character of uniqueness to the bastioned front.

3. The restoration of the 'Rocca' may offer great opportunities. Its spaces can be reused for a museum of the history of the State of the Presidios, which together with the 


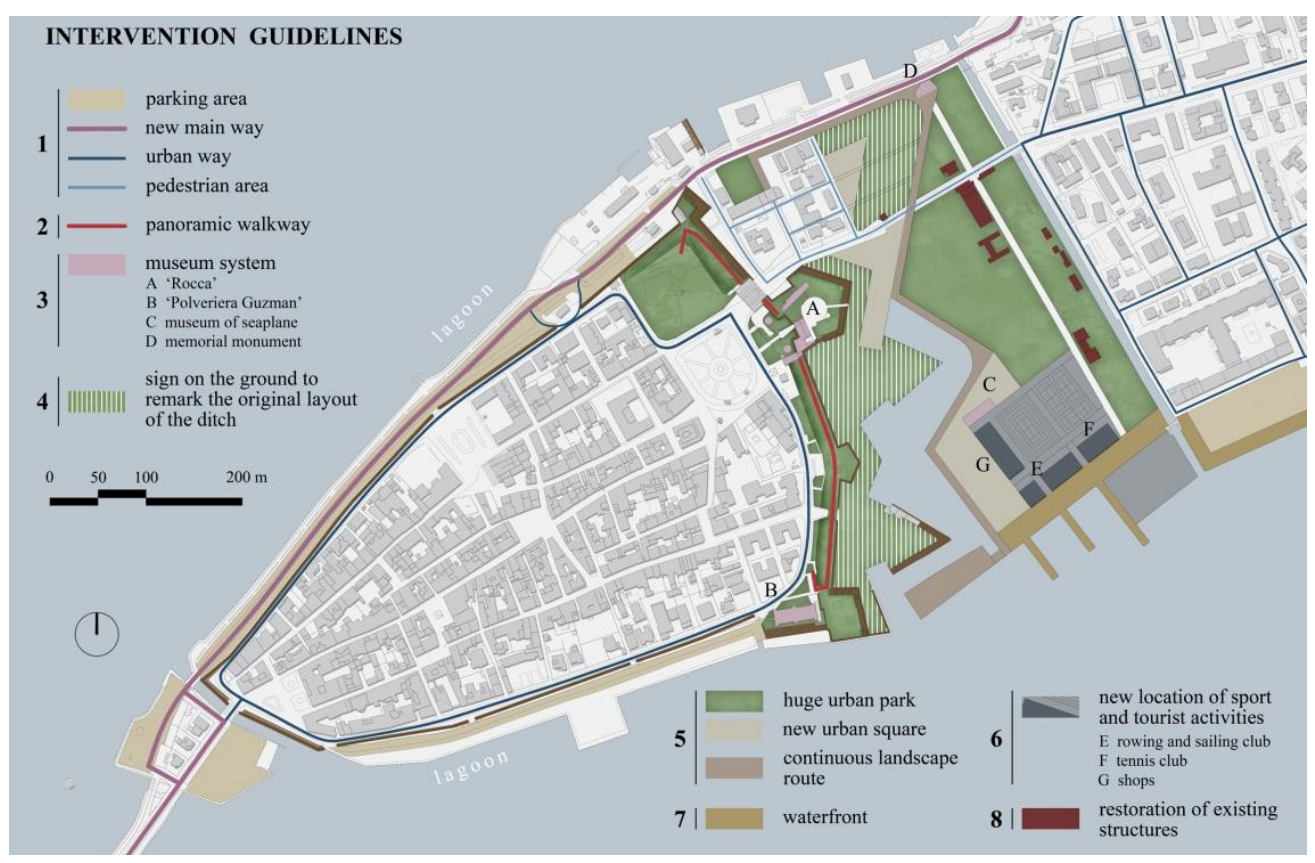

Fig. 9- Summery scheme of the intervention guidelines for the valorization of Orbetello bastioned front

archaeological museum in the 'Polveriera Guzman' and spaces dedicated to the history of the aviation in the former seaplane base area, could complete the museum system of Orbetello.

4. The sports activities placed at the foot of the bastioned front should be removed. This could allow to reopen the 'Fosso Reale' as much as possible, and where it is not possible, a sign on the ground could remark the original layout of the ditch.

5. The area of the former seaplane base, the 'Parco delle Crociere' and the whole apparatus of the fortifications should be recovered as a huge urban park; it may have a deep effect on the quality of life of citizens, turning a residual and degraded area in a system of public green areas and facilities, in an intermediate position between the historical centre and the newer quarter, and transversely between the two sides of the lagoon. Here, therefore, the existing cycle and pedestrian paths system must converge. Focusing also on the design of a continuous tourist route, the 'Porta del Soccorso' and the
'Porta a Terra Externa' have to be restored and reconnected to the walls.

6. The existing sport facilities include soccer and tennis fields, rowing and sailing clubs. Since the time of the seaplane base, sport activities have characterized this area, and over time, they have become increasingly present, catalysing important international events. The rowing and sailing activities cannot be moved, because they require an appropriate access to the lagoon that today is done using the old slides for seaplanes. These activities are therefore compatible with the place but they must be replaced away from the walls and organically structured, in full respect of the landscape values.

7. The urban park could be also an opportunity for traders, thanks to the realization of a new waterfront along the south-eastern bank of the former seaplane base, with commercial activities and tourist facilities.

8. It is important also to preserve the historical memory of the seaplane base, recovering as much as possible the existing and architecturally significant structures, giving them new appropriate functions. 


\section{Conclusions}

This study showed that the recovery of the bastioned front of Orbetello have to be necessarily thought inside a larger urban project, if we would give new value and function to these important historical and architectural heritage of the city. As we said, it is therefore central to intervene on the former seaplane base area, taking advantage of its attractive potentialities.

The City Administration has paid up to the present little attention to the management of this area. The participative process that has recently started opens, however, new perspectives for the regeneration of the area and the fortifications.
The study aims to help also operators in the identification of values and criticism of the area, in order to offer new causes for reflection in the definition of an intervention strategy.

\section{Acknowledgments}

All the graphic elaborations are by Alessio Cartei.

\section{Abbreviations}

ASSi, Archivio di Stato di Siena.

GFU, Galleria Fotografica degli Uffizi, Firenze.

\section{References}

Addonisio M. (2000). Orbetello tra storia e recupero urbano. Innocenti. Grosseto.

Ademollo A. (1883). L'assedio di Orbetello dell'anno 1646. Tipografia di Enrico Cappelli. Grosseto.

Bischi G. (1994). Orbetello: le origini, le mura, i nomi. Caletra. Grosseto.

Caciagli G. (1992). Lo Stato dei Presidi. Arnera. Pontedera.

Carandini A. (1985). La romanizzazione dell'Etruria: il territorio di Vulci. Electa. Milano.

Cardarelli R. (1924 - 25). "Confini fra Magliano e Marsiliana; fra Manciano e Montauto Scerpenna Stachilagi; fra Tricosto e Ansedonia; fra Orbetello e Marsiliana; fra Port'Ercole e Monte Argentario (28 dicembre 1508 - 2 marzo 1510)". Maremma. I. II.

Maioli Urbini N. (1985). "La cinta fortificata di Orbetello e lo stato dei Presidi: vicende costruttive e notizie storiche". Bollettino d'Arte. VI (31-32).

Milanesi G. (1885). Dell'edificazione d'una città sul Monte Argentario. Ragionamenti di Claudio Tolomei e Pietro Cataneo (1544-1547). Tipografia dell'Arte della Stampa. Firenze.

Pellegrini E. (1992). Le fortezze della Repubblica di Siena: vicende edilizie, significato strategico, condizioni operative dell'architettura fortificata rinascimentale nel conflitto tra Francia e Impero per il controllo del territorio senese. Il Leccio. Siena.

Raveggi P. (1933). Orbetello antica e moderna. Cooperativa Tipografica Fascista La Maremma. Grosseto.

Raveggi P. (1939). "Recenti ritrovamenti nell'agro Cosano e Talamone”. Storia Etrusca. n. 13.

Rombai L., Ciampi G., De Vita M., Spini G. (1979). Cartografia storica dei Presidios in Maremma (secoli XVI-XVIII). Consorzio Universitario della Toscana Meridionale. Siena.

Naldini M., Taddei D. (2003). Torri, castelli, rocche, fortezze : guida a mille anni di architettura fortificata in Toscana. Polistampa. Firenze. 